\title{
Sociocultural and Ecological Dynamics of Green Spaces in Brazzaville (Congo)
}

\author{
Victor Kimpouni (D, , ${ }^{1,2}$ Jean De Dieu Nzila $\mathbb{D}^{1,2}$ Noël Watha-Ndoudy, ${ }^{2,3}$ \\ Elodie Charleine Kokolo Bilongo, ${ }^{1}$ Salisou Yallo Mouhamed, ${ }^{2}$ Jean-Pierre Kampe, \\ and Dieudonné Louembe ${ }^{2}$
}

\author{
${ }^{1}$ École Normale Supérieure, Université Marien Ngouabi, BP 237 Brazzaville, Congo \\ ${ }^{2}$ Institut National de Recherche Forestière (IRF), BP 177 Brazzaville, Congo \\ ${ }^{3}$ Faculté des Sciences et Techniques (FST), BP 69 Brazzaville, Congo
}

Correspondence should be addressed to Victor Kimpouni; vkimpouni@yahoo.com and Jean De Dieu Nzila; jddnzila@yahoo.fr

Received 19 July 2019; Accepted 9 November 2019; Published 13 February 2020

Academic Editor: Béla Tóthmérész

Copyright ( 2020 Victor Kimpouni et al. This is an open access article distributed under the Creative Commons Attribution License, which permits unrestricted use, distribution, and reproduction in any medium, provided the original work is properly cited.

\begin{abstract}
The study was conducted in Brazzaville, and data collection covers the period from May to June 2017. The methodology is based on literature review and floristic and equipment inventory. Nine green spaces spread over two out of nine townships in the capital city. Four are located in Bacongo and five in Poto-Poto. According to the classification standards, 5 squares and 4 gardens were studied. Except for one square, all the others, including the gardens, are planted with trees. The equipment inventory lists 183 benches, including $63.83 \%$ permanently and/or partially in the sun, 4 playgrounds, no games for children, and 3 cultural monuments. The flora and health of the trees stands shows 186 trees and 279 shrubs, all corresponding to 26 species. An examination of the health status reveals that $57 \%$ of trees show anthropogenic injuries. Floral analysis shows that exotic plants (76.92\%) predominate over local plants $(23.07 \%)$. The average basal area of trees in all green spaces is $1.95 \mathrm{~m}^{2} \cdot \mathrm{ha}^{-1}$. The diametric structure is erratic within all green spaces, with a dominance of large diameter subjects. This leads to poor natural regeneration of woody plants. The green spaces in Brazzaville, which are very unevenly distributed within the urban fabric, do not meet the international standards disseminated by the World Health Organization (WHO) and do not fully play their biodiversity conservation and recreational and ecological functions. History of green spaces in Brazzaville states that no creation was born after independence. The existing land has been reduced in size, and the new land has been used for other purposes.
\end{abstract}

\section{Introduction}

The term green space is not new, and Choay and Merlin [1] report that this term first appeared in 1925, coined by Forestier, park curator, Paris garden. It spread in the 1950s, when it designated open and unpaved areas [2].

The green space designates, commonly in an urban or suburban area, an area with vegetation, ranging from a simple square to a large park through road plantations. Green spaces embellish the environment of cities according to several modes such as social as a place of rest and walk within everyone's reach; biological for the production of oxygen by trees and their contribution to the mitigation of several nuisances related to climate, and human health and economic benefits [3-6]. It should be noted that these designations meet criteria inherent to the area covered [7].

Areas of natural urban and periurban forests around the world are shrinking dramatically, and with them biodiversity is eroding [8]. Green spaces would be one of the ideal solutions to this phenomenon $[9,10]$. In addition to biodiversity conservation, they would, as in other countries, be appropriate environments for environmental education, introducing the scientific popularization of ecological phenomena in which the tree interacts closely with its natural environment $[11,12]$. Although they are vectors of pollution, the services rendered by trees through direct and indirect benefits are no longer to be demonstrated. The aspects cited as examples are air purification, dust retention, 
chemical air cleaners, noise pollution, soil protection, thermoregulation, climate regulation, and bio-geochemical cycle $[4,9,13-16]$. In the role of air pollution control and thermoregulator, Vergriete and Labrecque [17] show that plants and/or frequenting green spaces reduce the risks of certain ailments such as stress, respiratory infections, and migraines [18-23].

With the promulgation of the World Health Organization (WHO) Healthy Cities Programme [24, 25], the environment is considered a determining factor for the comfort, well being, and health of all. More and more, we are becoming aware of the fact that the environment in which the population lives is preponderant for its physical and moral balance. Among the means of improving this framework, green space is a very important component [26]. Indeed, green space is greatly valued for its contribution to the quality of life in the urban environment. Efforts to improve urban centres in developed countries have almost all been accompanied by attention to the creation, development, and use of green space [27].

In Africa, and more particularly in Congo, the place of the green space has never been the subject of real attention. Green spaces are unevenly distributed in the urban area, and postcolonial neighbourhoods are generally the most neglected [28]. There is also very little natural regeneration of these trees, most of which are senescent. Most species are ornamental and exotic [29]. Today, these nonfunctional and constantly degrading green spaces do not fulfil their primary vocation (ecological, biodiversity conservation, social, and recreational) and play only a derisory role [12].

More than half a century since the Congo gained independence, the urban plan of the city of Brazzaville has remained static on the development offer of green spaces and on the quality of life. The colonial period was marked by the creation of green spaces for an attractive, green, and relaxing urban living environment. This embellishment is based on the exploitation of the virtues of native and nonnative tree species [28, 29].

In the city of Brazzaville, the areas and facilities devoted to recreational green spaces are clearly insufficient and inadequate or even unsuitable for some. Since the 1960s, there has been a growing public interest in recreation and leisure. Rest after a working day and during holidays has become a necessity. Thus, offering the citizen an adequate framework for relaxation should be a permanent feature in any urban development plan.

The involvement of green spaces in the well being of the urban community of Brazzaville and the mitigation of the harmful effects of global climate change are the foundations of this study. The main objective of this study is to review the management of green spaces in Congo and particularly in Brazzaville, given that green spaces play an important recognized role in the conservation of biodiversity in general and plant diversity in particular and in the provision of goods and services to the population.

\section{Materials and Method}

2.1. Study Environment. Created in 1884, the city of Brazzaville, the capital of the Republic of Congo, is located on the banks of the Congo River (Figure 1), in the south of the country between $04^{\circ} 04^{\prime} \mathrm{S}$ and $15^{\circ} 02^{\prime} \mathrm{E}$ [30] covering an area of $326.40 \mathrm{~km}^{2}$ with an estimated population of $1,373,382$ $[31,32]$. Administratively, the Brazzaville autonomous department has 9 townships.

The climate in Brazzaville is humid tropical, with a rainy season from October to May, a dry season from June to September (Figure 2(a)), an average annual temperature of about $25^{\circ} \mathrm{C}$, and an average annual rainfall of $1,400 \mathrm{~mm}$ [33, 34]. March, April, and November are the rainiest months and June, July, August, and September are the driest (Figure 2(a)). Relative humidity is particularly high, always above $70 \%$ (Figure 2(b)), with an absolute minimum in August and September and a relative minimum in February and March. The minimum varies between 50 and $60 \%$, the maximum vary from 88 to $94 \%$. Evaporation (Figure 2(b)) shows a relative maximum from February to March and an absolute maximum in August and September [35]. The average annual sunstroke varies between 1,700 and 2,000 hours. The insolation curve has two maxima from March to May and in November and minima from June to August (Figure 2(c)).

\subsection{Material}

2.2.1. Study Material. The study material consists mainly of trees, shrubs, grasses, rest facilities, leisure facilities, and cultural monuments. The trees and shrubs were counted and identified, while the herbs were simply identified. The measurement of woody trees including the diameter at breast height $(\mathrm{DBH}) \geq 10 \mathrm{~cm}$ at $1.30 \mathrm{~m}$ height is systematically carried out. It is noted concomitantly that the individuals present signs of anthropic aggression (removing the bark of the trees). In addition, all cultural facilities and monuments have been identified. Finally, the area of each green space is evaluated.

2.2.2. Classification and Nomenclature of Green Spaces. In urban or periurban areas, green spaces are vegetated areas whose typology is based on precise criteria based on the area covered [7, 36-38]. Thus, we distinguish the following different types of spaces:

(i) Square: area less than 1 ha

(ii) Proximity garden: area between 1 and 4 ha

(iii) Urban park: area greater than 5 ha

(iv) Periurban park: area greater than 100 ha

Parks often offer water supply points, afforestation beds, and ornamental trees, but also created spaces such as lawns. Their location shows a recreational, sports, or relaxation vocation, with the presence of playgrounds, sports equipment, and benches. However, a public garden and a square are small spaces. The public garden is designed as a place to relax, and a square is seen as a meeting place. According to WHO, at least $10 \mathrm{~m}^{2}$ of green space in urban centres and $25 \mathrm{~m}^{2}$ in periurban areas are recommended per inhabitant $[38,39]$. 


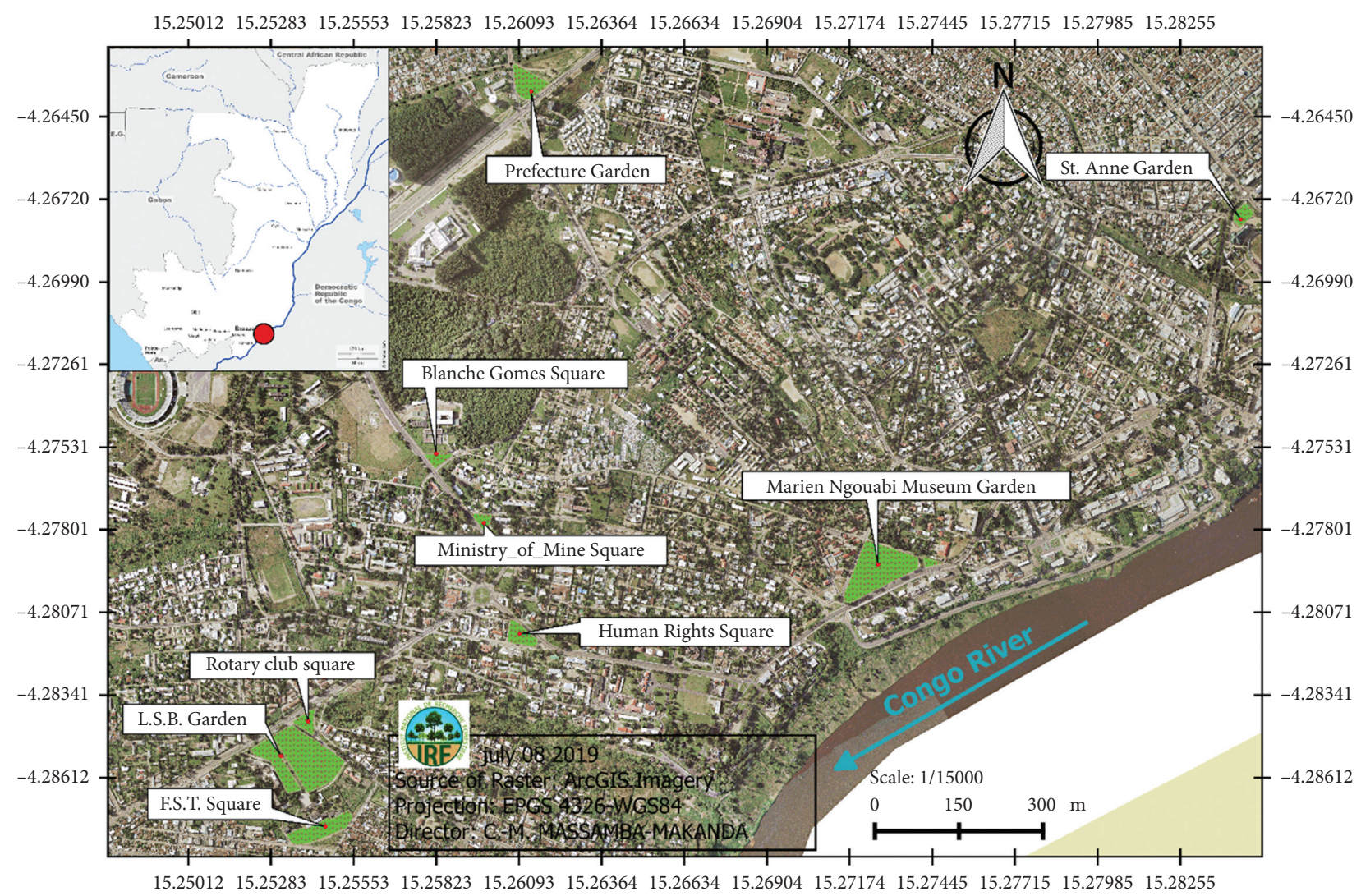

FIGURE 1: Location of green spaces within the Brazzaville urban area.

According to this nomenclature, the city of Brazzaville has 5 squares (Faculty of Science and Technology (FST), Rotary Club Square (PR), Ministry of Mines (MM), Human Rights (DH) and Blanche Gomez (BG)) and 4 gardens (Pierre Savorgnon de Brazza (PSB), Prefecture Hotel (HP), Saint-Anne (SA), and Marien Ngouabi Museum (MMN)).

2.3. Study Method. The study method is based on literature data and inventory data from the various green spaces. The literature data made it possible to take stock of green spaces, in particular their characteristics and their standard.

The floristic inventory is based on the identification of all species in the green space, the counting and measurement of woody $\mathrm{DBH}(\mathrm{DBH} \geq 10 \mathrm{~cm})$. The parameters monitored are frequency, density (number of individuals per unit area), DBH (diameter at breast height), basal area (ST), and anthropogenic effects.

The inventory of facilities concerns those intended for rest, leisure, historical, and/or cultural monuments present in each green space. The location of the benches in relation to the vegetation cover (under shade and/or exposed to the sun) was also taken into account.

\subsection{Expression of Phytoecological Results}

(i) Frequency: number of surveys where the taxon is present relative to the total number of surveys (ii) Shannon diversity index: $H^{\prime}=-\sum_{i=1}^{S} \mathrm{pi} \cdot \ln \mathrm{pi}$ with $\mathrm{pi}=\mathrm{ni} / n$ (ni $=$ number of individuals of species " $i$ "; $n=$ total number of individuals of all species)

(iii) Maximum diversity index: $H^{\prime} \max =\ln (S)$ with $S=$ total species

(iv) Equitability and/or regularity index (from Pielou): $\mathrm{Eq}=H^{\prime} / H_{\max }^{\prime}$

(v) Jaccard similarity coefficient $(\%)=100 \times(\mathrm{nc} /$ $(\mathrm{na}+\mathrm{nb}-\mathrm{nc}))$ with na $=$ number of specimens from survey $\mathrm{a} ; \mathrm{nb}=$ number of specimens from survey $\mathrm{b}$; and $\mathrm{nc}=$ number of specimens common to both surveys

\section{Results}

3.1. Location and Status of Green Spaces in Brazzaville. Green spaces currently cover a very small total area of almost 13 ha or $0.04 \%$ of the urban area of Brazzaville (Table 1 ). There were 9 green spaces located exclusively in two townships (Bacongo and Poto-Poto) while the city of Brazzaville comprises 9 townships. These green spaces are divided, according to the floristic facies, into 2 types: green areas with trees and green areas without trees (Table 1).

\subsection{Floristic Diversity}

3.2.1. Floral Composition. The inventory reveals 465 woody individuals corresponding to 22 species. They are 


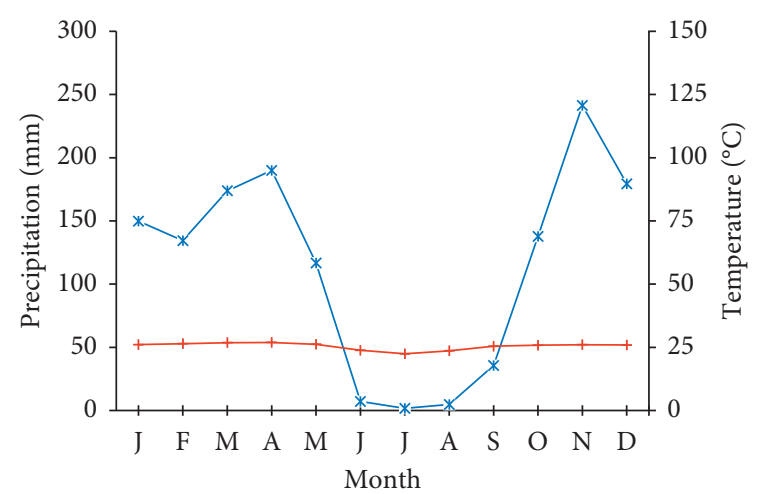

$-*-$ Precipitation $(\mathrm{mm})$
+ Temperature $^{\circ} \mathrm{C}$

(a)

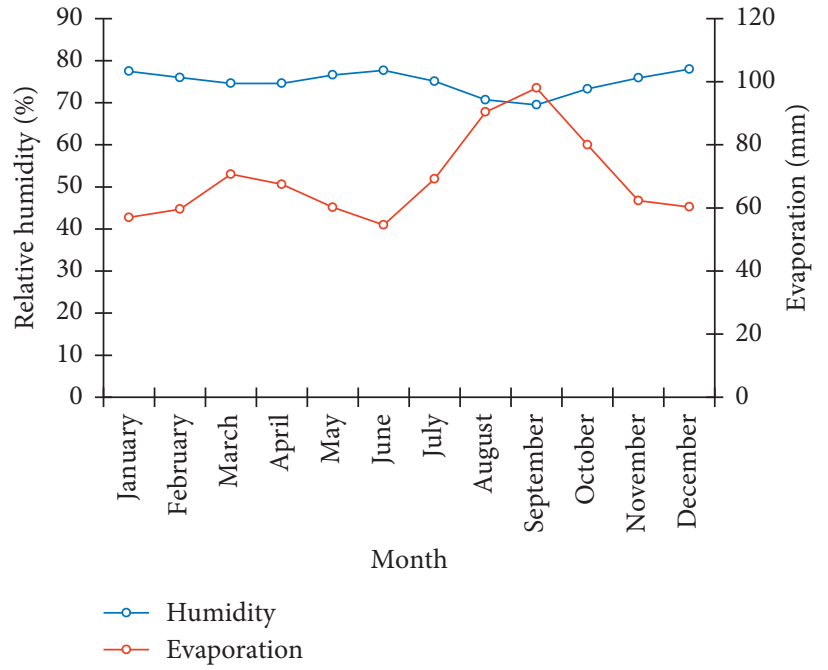

(b)

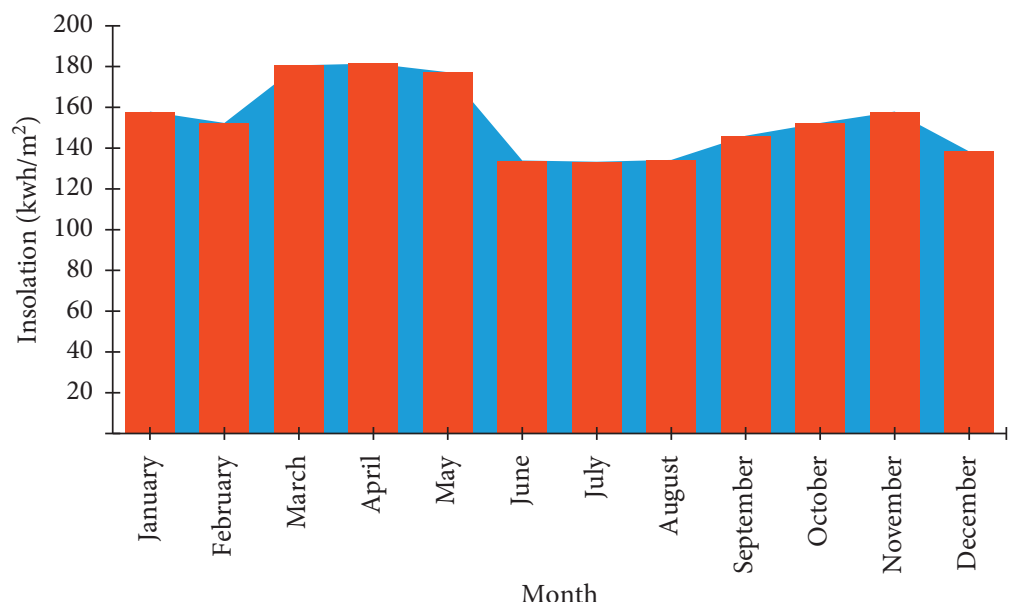

(c)

Figure 2: Climate parameter data for the Brazzaville area (source: ANAC, 2017). Ombrothermic curve (a); relative humidity and evaporation (b); insolation (c).

TABLE 1: General data on Brazzaville green spaces and location.

\begin{tabular}{|c|c|c|c|c|c|c|c|}
\hline Green spaces & Trees number & $H^{\prime}$ & $H_{\max }^{\prime}$ & Eq. & Aire (ha) & Status & Townships \\
\hline \multicolumn{8}{|l|}{ Arborer } \\
\hline Savorgnan de Brazza (PSB) & 48 & 1.50 & 1.79 & 0.83 & 3.95 & Garden & \multirow{5}{*}{ Bacongo } \\
\hline Faculty of Science and Technology (FST) & 25 & 0.59 & 0.69 & 0.85 & 0.65 & Square & \\
\hline Rotary club (PR) & 13 & 0.99 & 1.38 & 0.71 & 0.27 & Square & \\
\hline Ministry of Mines (MM) & 4 & 0.21 & 1.60 & 0.13 & 0.19 & Square & \\
\hline Prefecture hotel (HP) & 7 & 0.84 & 1.09 & 0.77 & 1.05 & Garden & \\
\hline Sainte-Anne (SA) & 5 & 0.80 & 1.03 & 0.77 & 1.60 & Garden & \multirow[t]{3}{*}{ Poto-poto } \\
\hline Marien Ngouabi Museum (MMN) & 24 & 1.94 & 2.39 & 0.84 & 4.10 & Garden & \\
\hline Human rights $(\mathrm{DH})$ & 16 & 1.26 & 1.94 & 0.64 & 0.90 & Square & \\
\hline \multicolumn{8}{|l|}{ Nonarborer } \\
\hline Blanche Gomez (BG) & 0 & 0.53 & 1.38 & 0.38 & 0.21 & Square & \\
\hline Total area (ha) & \multicolumn{7}{|c|}{12.92} \\
\hline
\end{tabular}

$H^{\prime}$, Shannon index; $H_{\text {max }}^{\prime}$, maximum diversity; Eq, equitability.

divided into 142 trees representing $30.5 \%$ of the inventory or an average of $16 \pm 3.7$ trees per green space. As for the 323 shrubs, they account for $69.5 \%$ of all woody trees. This floral procession is composed of 6 native species $(27.3 \%)$ and 12 nonnatives $(72.7 \%)$. The centres of origin are Asia (36.36\%); Africa and America with $22.73 \%$ each; and Australia and Madagascar with $9.09 \%$ per entity (Table 2). 
TABLE 2: Synopsis of the flora of Brazzaville green spaces.

\begin{tabular}{|c|c|c|c|c|c|c|c|c|c|c|c|}
\hline \multirow{2}{*}{ Species } & \multirow{2}{*}{ Origin } & \multirow{2}{*}{ Freq. (\%) } & \multicolumn{9}{|c|}{ Density } \\
\hline & & & SB & PR & FST & HP & SA & MM & BG & MMN & $\mathrm{DH}$ \\
\hline Millettia laurentii De Wild. & Central Africa & 33.33 & 5.3 & $11^{*}$ & - & - & - & - & - & 0.7 & - \\
\hline Ficus benghalensis L. & Asia & 77.78 & 1.0 & - & $18^{*}$ & 9.5 & 6.3 & - & $59^{*}$ & 2.4 & $40^{*}$ \\
\hline Lagestroemia speciosa Persoon & Asia & 11.11 & 2.4 & - & - & - & - & - & - & - & - \\
\hline Cocos nucifera $\mathrm{L}$ & Pacific & 22.22 & 3.3 & - & - & - & - & - & - & 0.5 & - \\
\hline Senna siamea Lamack & Asia & 33.33 & 0.8 & $1^{*}$ & - & - & - & - & - & 0.2 & - \\
\hline Thevetia peruviana Schumann & America & 11.11 & 0.5 & - & - & - & - & - & - & - & - \\
\hline Delonix regia Bojer & Madagascar & 22.22 & - & $1^{*}$ & - & - & - & - & - & 0.2 & - \\
\hline Roystonea regia Kunth & America & 22.22 & - & $6^{*}$ & - & - & - & $50^{*}$ & - & - & - \\
\hline Terminalia mantaly L. & Madagascar & 44.44 & - & - & $7^{*}$ & - & - & $1^{*}$ & - & 0.2 & $2^{*}$ \\
\hline Cupressus lusitamea Miller & America & 11.11 & - & - & - & - & - & $2^{*}$ & - & - & - \\
\hline Mangifera indica L. & Asia & 22.22 & - & - & - & - & - & $1^{*}$ & - & - & $1^{*}$ \\
\hline Leea guineensis & America & 11.11 & - & - & - & - & - & $3^{*}$ & - & - & - \\
\hline Allamanda cathartica $\mathrm{L}$. & America & 11.11 & - & - & - & - & - & $2^{*}$ & - & - & - \\
\hline Ficus asperifolia Miquel & Africa & 11.11 & - & - & - & - & - & - & $1^{*}$ & - & - \\
\hline Ixora coccinea $\mathrm{L}$ & Australia & 11.11 & - & - & - & - & - & - & $2^{*}$ & - & - \\
\hline Caesalpinia pulcherrima Swartz & Asia & 33.33 & - & - & - & - & - & - & $7^{*}$ & 2.2 & $8^{*}$ \\
\hline Millettia sp. & Africa & 33.33 & - & - & - & 5.7 & - & - & - & 0.2 & $3^{*}$ \\
\hline Acacia auriculiformis Allan & Africa & 11.11 & - & - & - & 0.9 & - & - & - & - & - \\
\hline Adansonia digitata $\mathrm{L}$. & Africa & 11.11 & - & - & - & - & 0.6 & - & - & - & - \\
\hline Eucalyptus sp. & Australia & 33.33 & - & - & - & - & 2.5 & - & - & 1.7 & $6^{*}$ \\
\hline Terminalia catappa L. & America & 11.11 & - & - & - & - & - & - & - & 2.2 & - \\
\hline Elaeis guineensis Jacq. & America & 11.11 & - & - & - & - & - & - & - & - & $4^{*}$ \\
\hline Cynodon dactylon Persoon & Europe & 66.67 & + & - & + & + & - & - & + & + & + \\
\hline Paspalum notatum Fluggé & Pantropical & 88.89 & + & + & - & + & + & + & + & + & + \\
\hline Sida acuta L. & America & 22.22 & + & - & - & - & - & - & - & + & - \\
\hline Eleusine indica Garthner & Tropical Africa & 22.22 & + & - & - & - & - & - & - & + & - \\
\hline Species number & $1-$ & - & 10 & 5 & 3 & 5 & 4 & 7 & 6 & 14 & 9 \\
\hline Trees number & - & - & 48 & 13 & 25 & 7 & 5 & 4 & 0 & 24 & 16 \\
\hline Trees peeling & - & - & 31 & 11 & 10 & 3 & 1 & 3 & 0 & 16 & 6 \\
\hline Peeling rate $(\%)$ & - & - & 64.6 & 84.6 & 40 & 73 & 20 & 42.8 & 0 & 66.7 & 37.5 \\
\hline
\end{tabular}

Lycée Pierre Savorgnan de Brazza (PSB), Rotary Place (PR), Prefecture Hotel (HP), Sainte-Anne (SA), Ministry of Mines (MM), Blanche Gomez (BG), Marien NGOUABI Museum (MMN), Human Rights (DH), presence $(+)$, absence $(-)$, data on areas below hectare $\left(^{*}\right)$, and frequency (freq).

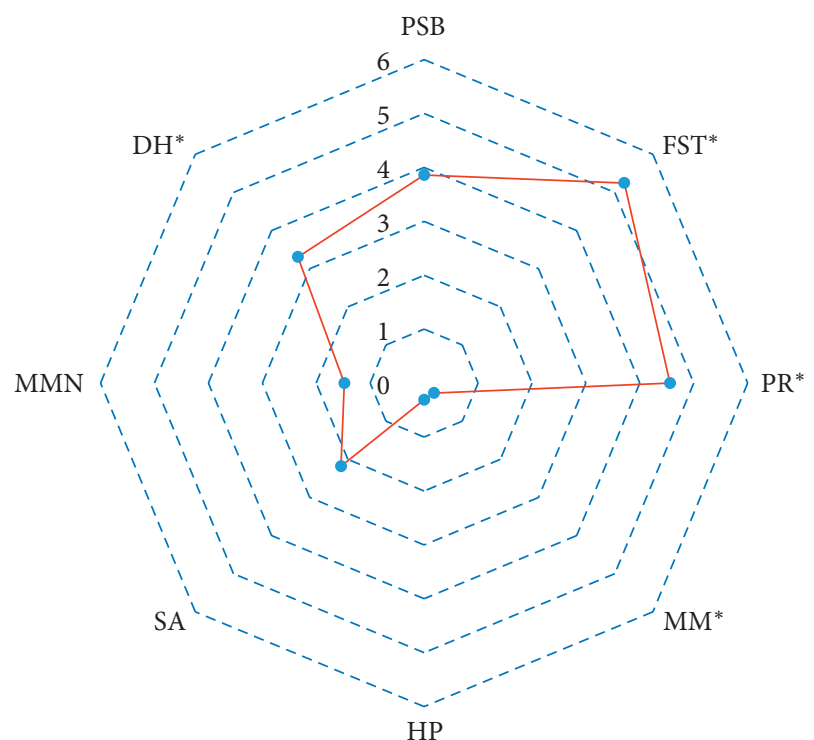

Figure 3: Woody basal area in the different green spaces. Prefecture garden (HP), Saint-Anne garden (SA), Marien Ngouabi Museum garden (MMN), Ministry of Mines square (MM), Pierre Savorgnon De Brazza garden (PSB), Rotary Club square (PR), Faculty of Science and Technology square (FST), Human rights square $(\mathrm{DH})$, and $\left({ }^{*}\right)$ data relating to areas of less than 1 ha.
3.2.2. Bioecological Indices. The similarity coefficient of Jaccard and woody flora, between green spaces varies from 0 to $41.66 \%$. This data reveals that the floristic composition is very heterogeneous from one medium to another (Table 1). It would be the corollary of the invasion of the allochthonous flora in the urban arboriculture in Brazzaville.

The average Shannon biodiversity index for the 9 green spaces is $0.96 \pm 0.14$ (Table 1 ). The values range from 0.21 to 1.94. The maximum diversity achieved by these formations is $1.48 \pm 0.13$ on average, for an average range of 1.03 to 2.30 . The Pielou index is $0.66 \pm 0.06$ on average, with a range of numbers oscillating from 0.13 to 0.85 . On the whole, these data mark the paucispecific and paucifloristic characters of the mentioned green spaces.

\subsection{Stand Structure Parameters}

3.3.1. Frequency. Taxon frequencies vary from 1 to 8 . Except for herbaceous plants such as Cynodon dactylon (66.7\%) and Paspalum notatum (88.9\%) which are almost omnipresent, woody plants remain discreet (Table 2). The species most represented in green spaces are Ficus benghalensis $(77.8 \%)$ and Terminalia mantaly (44.4\%). It is interesting to note the 


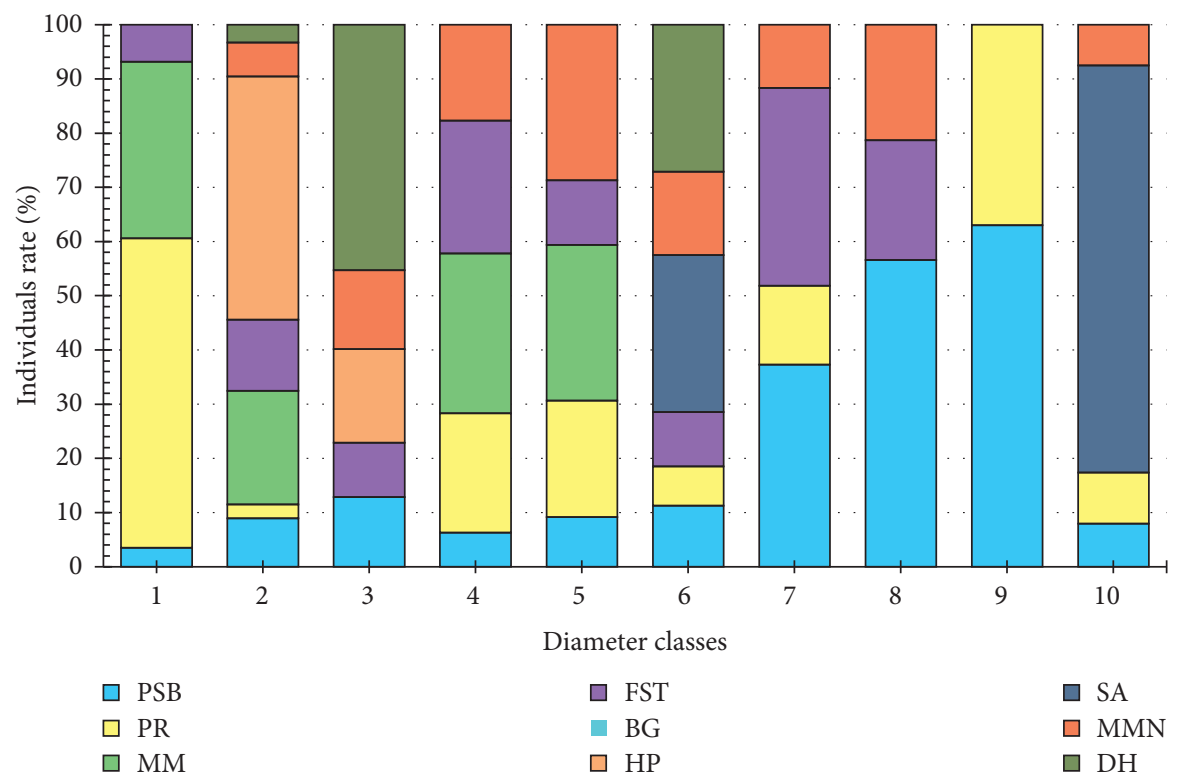

FIgURE 4: Diametric structure of trees in green spaces in Brazzaville. Prefecture garden (HP), Saint-Anne garden (SA), Blanche Gomes garden (BG), Marien Ngouabi Museum garden (MMN), Ministry of Mines square (MM), Pierre Savorgnon De Brazza garden (PSB), Rotary Club square (PR), Faculty of Science and Technology square (FST), and Human rights square (DH).

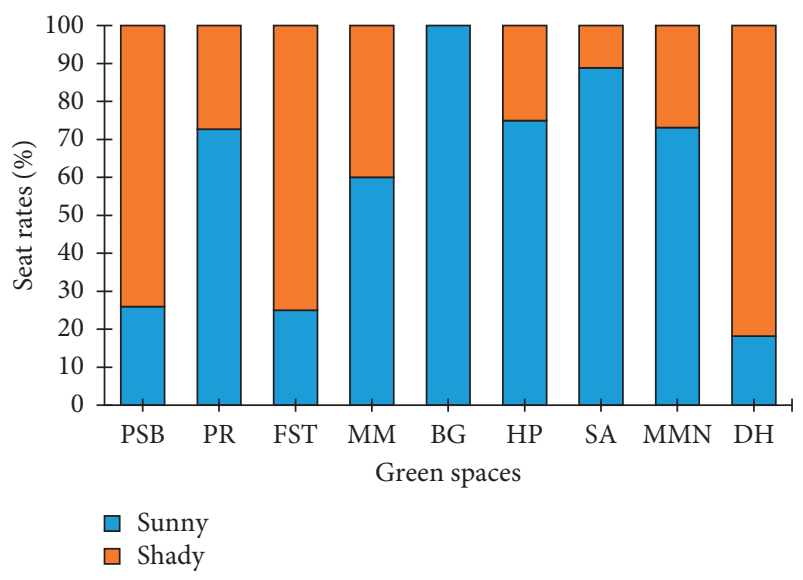

FIGURE 5: Seating and sunshine in the various green spaces. Prefecture garden (HP), Saint-Anne garden (SA), Blanche Gomes garden (BG), Marien Ngouabi Museum garden (MMN), Ministry of Mines square (MM), Pierre Savorgnon De Brazza garden (PSB), Rotary Club square (PR), Faculty of Science and Technology square (FST), and Human rights square (DH).

low representation of naturalized taxa such as Millettia laurentii (33.3\%), Terminalia catappa, and Adansonia digitata with, respectively, $11.1 \%$.

3.3.2. Density. Woody density in green spaces of at least 1 ha varies from 0.24 to 5.31 trees ha $^{-1}$, with numbers ranging from 1 to 59 individuals per green space. The most represented species are: Ficus benghalensis with 10.60 trees $\cdot \mathrm{ha}^{-1}$ (49.10\%); Millettia laurentii with 2.7 trees.ha ${ }^{-1}$ (18.81\%); Eucalyptus sp. with 1.31 trees.ha ${ }^{-1}(9.13 \%) ;$ Millettia sp. with 0.77 trees $\cdot \mathrm{ha}^{-1}$ (5.37\%); and Terminalia mantaly with 0.69 trees $\cdot \mathrm{ha}^{-1}(4.83 \%)$.

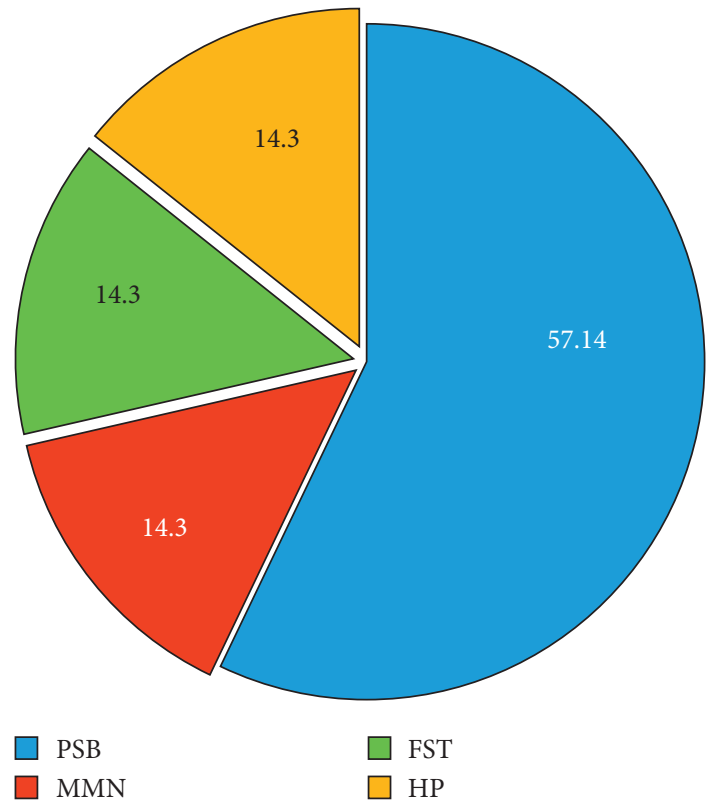

Figure 6: Cumulation of playgrounds and historical and/or cultural monuments by green spaces. Prefecture garden (HP), Marien Ngouabi Museum garden (MMN), Ministry of Mines square (MM), Pierre Savorgnon De Brazza garden (PSB), and Faculty of Science and Technology square (FST).

3.3.3. Tree Basal Area in the Green Spaces of Brazzaville. The projection of trunk sections on the ground per green space of at least 1 ha varies from 0.31 to $3.86 \mathrm{~m}^{2} \cdot \mathrm{ha}^{-1}$ (Figure 3). However, for those less than 1 ha, the value is between 0.26 and $5.25 \mathrm{~m}^{2}$ per green space.

3.3.4. Diametric Structure of Trees in Brazzaville' Green Spaces. The diametric structure of ligneous trees is declined in 


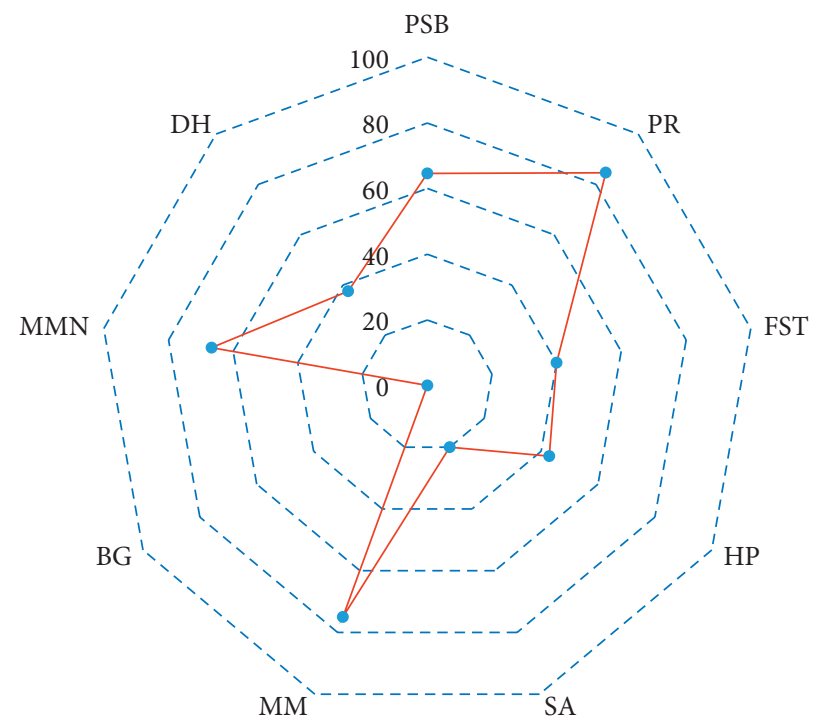

Figure 7: Rate of woody taxa debarked per green space. Prefecture garden (HP), Saint-Anne garden (SA), Blanche Gomes garden (BG), Marien Ngouabi Museum garden (MMN), Ministry of Mines square (MM), Pierre Savorgnon De Brazza garden (PSB), Rotary Club square (PR), Faculty of Science and Technology square (FST), and Human rights square (DH).

TABLE 3: Green space-inhabitants ratio in the municipality of Brazzaville.

\begin{tabular}{|c|c|c|c|c|c|c|c|}
\hline Townships & Men & Women & Total & Area $\left(\mathrm{km}^{2}\right)$ & Density $\left(\mathrm{hab} \cdot \mathrm{km}^{-2}\right.$ ) & Green spaces (ha) & Ratio $\left(\mathrm{m}^{2} /\right.$ ind.) \\
\hline Makélékélé & 145450 & 152842 & 298292 & 138.91 & 2147.38 & 0 & 0 \\
\hline Bacongo & 48223 & 50559 & 98782 & 70.60 & 1399.18 & 4.87 & 0.49 \\
\hline Poto-Poto & 48223 & 44883 & 93106 & 91.42 & 1018.44 & 8.05 & 0.86 \\
\hline Moungali & 82316 & 84403 & 166709 & 140.64 & 1185.36 & 0 & 0 \\
\hline Ouenzé & 89244 & 92813 & 182986 & 68.87 & 2656.98 & 0 & 0 \\
\hline Talangai & 167325 & 170661 & 337986 & 296.18 & 1141.15 & 0 & 0 \\
\hline Mfilou & 96818 & 99622 & 196440 & 1114.52 & 176.26 & 0 & 0 \\
\hline Total & 677599 & 695783 & 1373382 & 1921.14 & 714.88 & 12.92 & 0.094 \\
\hline
\end{tabular}

Source: CNSEE, 2010; CERAPE-SOFRECO, 2012.

erratic curves, for all species, notwithstanding their status as aesthetic and key factor of the well being of the green space (Figure 4). This structure denotes a natural regeneration deficit and the ageing of the stand following (i) the nonreplacement of the elderly subjects and (ii) letting nature do its work.

\subsection{Inventory of Equipment in the Green Spaces of Brazzaville}

3.4.1. Benches and Location. The inventory shows 188 benches, an average of $20.89 \pm 3.95$ per green space. Depending on their location, $63.83 \%$ of the resting facilities are exposed to the sun all day long, compared with the tree crown. This rate corresponds to an average of $13 \pm 3.33$ benches per green space. However, $36.17 \%$ benefit, at least partially, from the shade of woody trees during the day, either $8 \pm 1.7$ benches per green space on average. (Figure 5).

3.4.2. Playgrounds and Historical Monuments. Only 4 of the 9 green spaces studied have some leisure facilities and historic monuments (Figure 6). The presence rates of leisure facilities (sports field and other games) per green space are as follows: 7.5\% at Pierre Savorgnon De Brazza garden and 25\% at the Faculty of Science and Technology square. Historical and/or cultural monuments represent $33.33 \%$. Brazzaville green spaces are clearly underequipped and remain well away from international standards.

3.5. Tree Health in the Green Spaces of Brazzaville. Observation of the health of trees in green spaces in Brazzaville shows that the majority of them show tangible signs of human removing the bark of the trees. Overall, this inventory found that $57 \%$ of the 142 trees surveyed are barked. The aggression rates of the highest woody species are found in the Ministry of Mines square, Marien Ngouabi Museum garden, Pierre Savorgnon De Brazza garden, and Rotary Club square green spaces (Figure 7) where they vary between 40 and $84.6 \%$. The species valued by this activity are those that depend on proven phytotherapeutic properties: Mangifera indica, Millettia laurentii, Peltophorum pterocarpum, Senna siamea, and Terminalia catappa.

3.6. Ratio of Green Spaces to Population. With a cover of 12.92 ha of green spaces and an estimated population of $1,373,382$ inhabitants, the ratio of green space to population in the city of Brazzaville is $0.094 \mathrm{~m}^{2} /$ individual. This result is well below the accepted value of $10 \mathrm{~m}^{2}$ /individuals in urban areas. This is synonymous with a negative correlation 
between exponential urbanization and the installation of green spaces (Table 3). Thus, the green space needs expressed for the population of Brazzaville are currently estimated at $1,373.38$ ha of green space, a deficit of $1,360.46$ ha. The municipalities of Bacongo and Poto-Poto, which are the only ones with green spaces, need 98.78 and 93.11 ha of green spaces, respectively, with deficits of 93.91 and 85.06 ha of green spaces, respectively. The other communes, without green spaces, need 166.71 ha for Moungali; 182.99 ha for Ouenzé; 337.99 ha for Talangai, and 196.44 ha for Mfilou.

\section{Discussion}

\subsection{Direct and Indirect Benefits Associated with Green Spaces}

4.1.1. Green Spaces and Biodiversity. The floral analysis of green spaces in Brazzaville proves that these very paucispecific environments are also very poor floristically. This double weakness would correlate with the erosion of biodiversity caused by the drastic regression of natural urban and periurban forests $[8,40]$. This degradation of green spaces in Brazzaville does not allow these entities to provide goods and services that are vested in them $[4,9,13-16]$. The preponderance of exotic species, especially shrubs, does not guarantee the conservation and enhancement of the local flora [40]. A comparison of the specific and floristic diversity of green spaces and periurban forests in Brazzaville shows that they are more diversified $[8,41-45]$. However, most of their taxa are not present in green spaces. Considering that these green spaces have not been monitored, integrating the conservation dimensions of plant biodiversity, both local and exotic, and the extent of the area, since independence, it is difficult to make a decision on any correlation between these two parameters, despite some variations in the floristic composition.

4.1.2. Green Spaces and Quality of Life. The very low level of equipment, stricto sensu, of green spaces in Brazzaville coupled with the projection of sections of trunks on the ground, are elements that do not allow green spaces to fully play their ecological, environmental, and recreational functions $[9,12,13,17,23,46]$. Under a hot and humid climate, the city of Brazzaville is unable to mitigate the impacts of climate change (climate variability and quasipermanent heat waves and persistence of parasitic and vector-borne diseases) and air pollution by suspended particles, greenhouse gases, and metallic trace elements. Facilities such as playgrounds and sports facilities are crossroads for people from different social backgrounds, ethnicities, races, and generations (from young children to the elderly). This cohabitation seals and reinforces the sense of community belonging of the populations [9, 12, 23, 47, 48].

4.1.3. Green Spaces and Health. The low representativeness of green spaces throughout the city of Brazzaville, and the absence of green spaces in several boroughs, force the populations to live enclosed in dwellings or plots that are, for the most part, poorly developed. Thus, the green spaces of the city of Brazzaville do not offer the city dwellers the ideal conditions for evacuating daily stress and mitigating the psychological effects associated with occupational turpitudes and vicissitudes, various ailments such as musculoskeletal disorders, respiratory problems and migraines [18-23]. If these green spaces covered a sufficient area, they would not only encourage the practice of collective games, thus socializing, would ward off the risks of obesity associated with sedentarization $[24,49-53]$. This would reduce the budget devoted to health by the State and the population [4]. Optimizing the benefits of green spaces is to have them as close as possible to homes. Lessard and Boulfroy [54] estimate that a better response on quality of life and a marked reduction in medical care is achieved within a $500 \mathrm{~m}$ radius.

4.1.4. Combating the Effects of Climate Change. Global climate change affecting planet earth is not a marginal phenomenon in the Congolese context, as noted in the work of Bouka Biona and Mpounza [55], Samba and Nganga [33], and Samba et al. [34]. From these studies, the climatic impact is expressed in an increase in temperature and precipitation over almost the entire territory, despite some variations. Changing these two parameters inexorably affects biodiversity and with it the dynamics and functioning of ecosystems [56].

The vegetation cover of the green spaces of Brazzaville is very low to mitigate the effects of the urban heat island and pollution generated by the city, on the one hand $[5,6,9,16,57,58]$. On the other hand, reducing carbon and other greenhouse gas emissions to combat global warming has become a global issue [9]. However, DBH is a very important parameter in the evaluation of carbon sequestered by trees via allometric equations. The higher the $\mathrm{DBH}$, the more important the biomass, the more carbon sequestered the tree $[6,9,59,60]$. At a time when the majority of trees in green spaces are senescent, their carbon sequestration power and/or capacity remain very limited.

Most of the trees in the green spaces of Brazzaville have modest $\mathrm{DBH}$, they are stands that have aged, and have reached a point of equilibrium for carbon absorption. As stands approach maturity, growth rates and carbon uptake decrease $[9,61]$. These trees, which currently require more maintenance energy than for their growth, are characterized by a very low carbon sequestration capacity.

Because of the long life of these trees and their relatively large dimensions, these trees are true carbon stores and not carbon sinks [60]. Currently with the obvious impoverishment of citizens, green spaces have become essential elements of the traditional phytotherapeutic system, sources of wood energy, and wood crafts [62]. The majority of trees is barked and has senescence cavities. The exploitation of these virtues exposes the internal organs to attacks by microorganisms (cryptogamic), the corollaries of which are decay and the release of carbon sequestered in the atmosphere [62-66]. Thus, the fight against global climate change is not really ensured by the green spaces in Brazzaville, because their contribution is rather noted as a source of carbon emissions.

4.2. Efforts to Be Made in the Creation of Green Spaces. Despite the benefits of green spaces, which are no longer to be demonstrated, Brazzaville does not take this dimension 
into account in its urban planning [4]. The clear proof is that not all boroughs, new or old, have green spaces or even a reserved area in the various master urban plans. This lack of interest is reflected in the existence of the same green spaces dating from colonial times, some of which have had varying fortunes. Unless they disappear like that of the Maya-Maya Airport, they see their surface area greatly reduced like the Schoelcher area [28, 67]. Despite the presence of the environmental, hygiene, and quality-of-life services that exist in the town halls, the green spaces in Brazzaville have remained a colonial fact, in the eyes of the city's new managers. Indeed, we are far from meeting the internationally accepted standard of $10 \mathrm{~m}^{2}$ of green space per citizen in urban areas and $25 \mathrm{~m}^{2}$ in periurban areas $[4,7,38,39]$. This observation also applies to the avenue and/or alignment trees, which together inspired the name "Brazza la verte."

\section{Conclusion}

In the city of Brazzaville, the areas devoted to green spaces are very small. Thus, the green space/population ratio is almost zero, despite the international standard. The existing green spaces date from the colonial period and see their surface regressed, if they have not disappeared. Set up at a time when the city was born, all the green spaces are concentrated in the oldest townships of the city, although this one knew an important development during the last thirty years. This situation does not allow the entire population of Brazzaville to benefit directly or indirectly from green spaces. The need for green space is essential in urban areas, especially those with low incomes, as it helps to reduce health costs.

Brazzaville must develop and significantly increase the proportion of vegetated surface, taking into account the different needs of its population. Thus, urbanization policy should integrate the green space dimension for the well being of all, in order to meet the international standards of $21^{\text {st }}$ century urban cities. This policy will involve a rational and equitable rebalancing of local biodiversity conservation issues, environmental balances, recreational needs, and other associated values. Finally, our green spaces imperatively require developments oriented towards the replacement of all old trees with a preference for indigenous diversity on the other hand. This vision would lead the capital city to clearly fit into a policy to combat global climate change, by increasing carbon sequestration and improving the quality of life of urban and periurban populations.

\section{Appendix}

Overview of the green spaces revealing the location of the benches and the floristic deficit are shown in Figure 8.

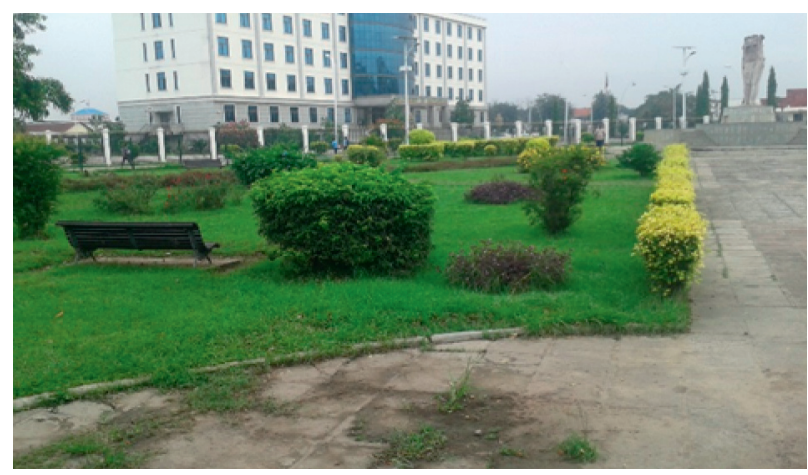

(a)

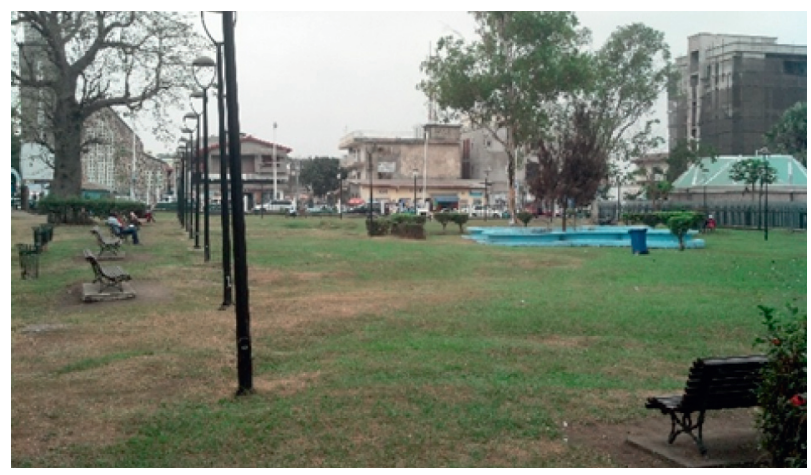

(b)

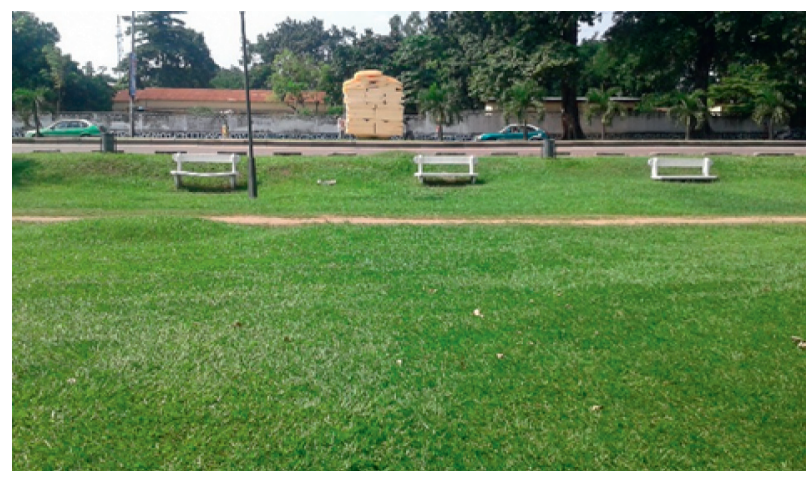

(c)

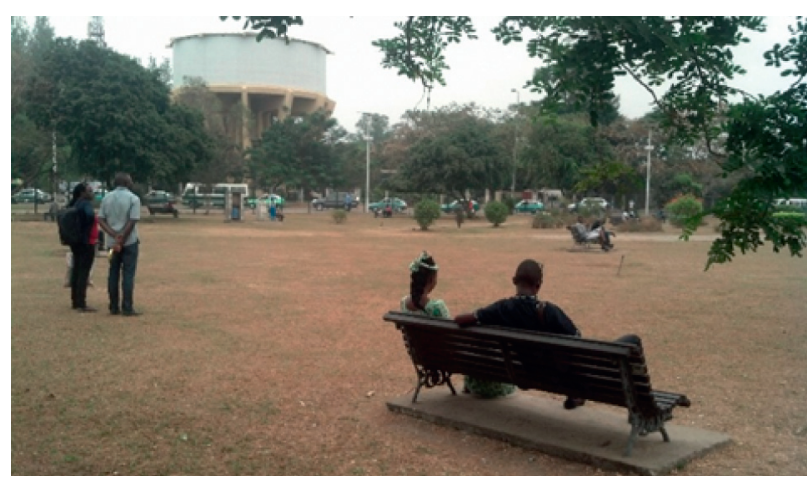

(d)

Figure 8: Continued. 


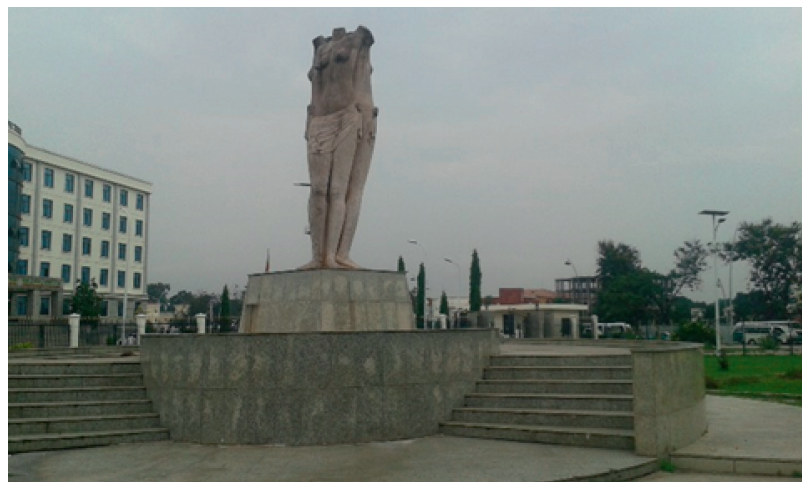

(e)

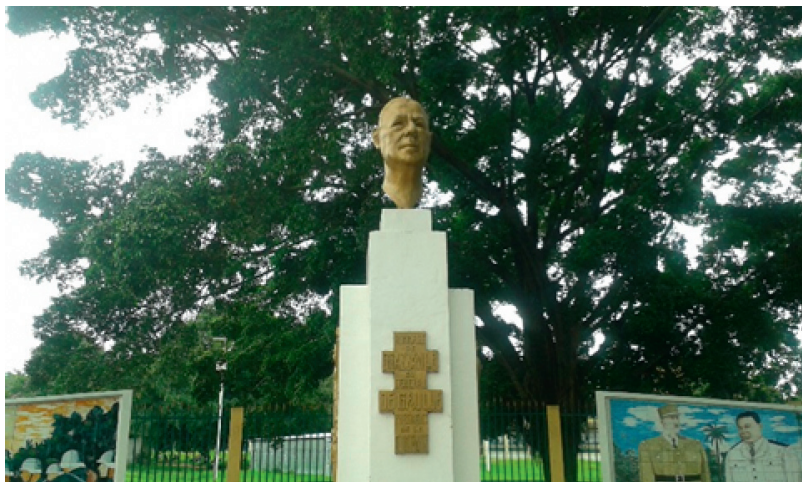

(f)

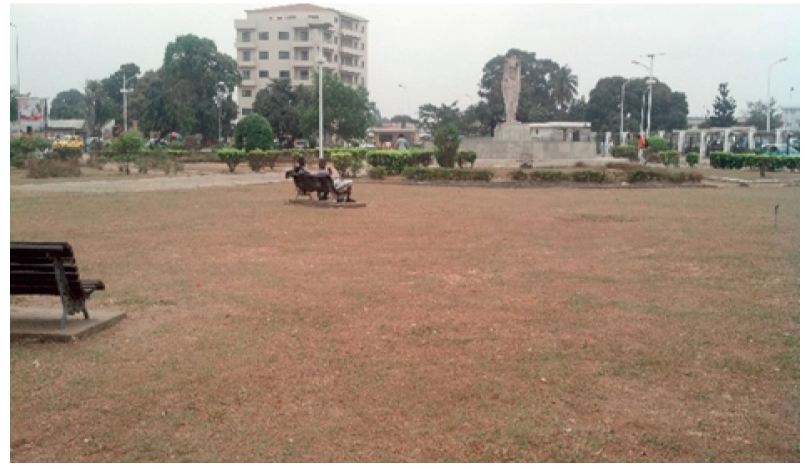

(g)

Figure 8: Prefecture hotel garden (a, d, and g); Sainte-Anne garden (b); Marien Ngouabi museum garden (c); and Lycée Pierre Savorgnon de Brazza garden (f).

\section{Conflicts of Interest}

The authors declare that they have no conflicts of interest.

\section{References}

[1] F. Choay and P. Merlin, Dictionnaire de l'Urbanisme et de l'Aménagement, Presses Universitaires de France, Paris, France, 4th edition, 2015.

[2] C. Stefulesco, L'urbaniste Végétal, Institut pour le développement Forestier, Paris, France, 1993.

[3] A. Camus, Dicovert: Dictionnaire des Jardins et Paysage, Edition Arcature, Paris, France, 1993.

[4] H. Li, W. Chen, and W. He, "Planning of green space ecological network in urban areas: an example of Nanchang,
China," International Journal of Environmental Research and Public Health, vol. 12, no. 10, pp. 12889-12904, 2015.

[5] S. Savic, J. Unger, T. Gál, D. Milosevic, and Z. Popov, "Urban heat island research of Novi Sad (Serbia): a review," Geographica Pannonica, vol. 17, no. 1, pp. 32-36, 2013.

[6] V. É. Molnár, B. Tóthmérész, S. Szabó, and E. Simon, "Urban tree leaves' chlorophyll-a content as a proxy of urbanization," Air Quality, Atmosphere \& Health, vol. 11, no. 6, pp. 665-671, 2018.

[7] J. P. Muret, Les Espaces Urbains, Concevoir, Réaliser et Gérer, Edition du Moniteur, Paris, France, 1976.

[8] V. Kimpouni, M. Y. Lenga-Sacadura, R. S. Kalath, L. Kiangana-Ngoyi, and L. Kiangana-Ngoyi, "Diversité floristique des épiphytes et hémiparasites vasculaires de l'écosystème forestier urbain de Brazzaville, Congo," Journal of Applied Biosciences, vol. 117, no. 1, pp. 11704-11719, 2017.

[9] N. Bouzou and C. Marques, "Les espaces verts urbains: lieux de santé publique, vecteurs d'activité économique," Union Nationale Des Entreprises Du Paysage, Paris, France, Rapport ASTERES, 2016.

[10] B. Hüse, S. Szabó, B. Tóthmérész, and B. Tóthmérész, "Mapping an ecological network of green habitat patches and their role in maintaining urban biodiversity in and around Debrecen city (Eastern Hungary)," Land Use Policy, vol. 57, pp. 574-581, 2016.

[11] Rousseau, "Les espaces verts en milieu urbain: avantage, problématiques et recommandation," Université de Sherbrooke, Sherbrooke, Canada, Essai de Maitrise en Environnement, 2008.

[12] C. C. Konijnendijk, M. Annerstedt, A. B. Nielsen, and S. Maruthaveeran, "Benefits of urban parks: a systematic review," IFPRA World, vol. 2012, no. 6, pp. 10-12, 2012.

[13] P. Ozenda, Les végétaux dans la biosphère, Editions Dunod, Paris, France, 1982.

[14] F. J. Convery, "Intégration d'un processus de plan national d'action pour l'environnement dans un cadre macroéconomique in: plans nationaux d'action pour l'environnement en Afrique," Gouvernement Irlandais, Institut pour l'environnement (University College), Dublin, Ireland, Compte rendu atelier du, 1990.

[15] Dubois, Des Arbres Pour Vivres en Santé, Editions Dunod, Paris, France, 1995.

[16] Apur, Développer le Végétal à Paris, les Nouvelles Règles du Plan Local D'urbanisme de Paris, Apur, Paris, France, 2004.

[17] Y. Vergriete and M. Labrecque, Rôles des Arbres et des Plantes Grimpantes en Milieu Urbain: Revue de la Littérature et Tentative d'Extrapolation au Contexte Montréalais, Université de Montréal, Montreal, Canada, 2007.

[18] G. Coronio and J. P. Muret, Loisirs: Guide Pratique des Équipements. Paris Centre de Recherche et de Rencontres D’urbanisme, Édité par Centre de recherche d'urbanisme, Paris, France, 1976.

[19] R. S. Ulrich, R. F. Simons, B. D. Losito, E. Fiorito, M. A. Miles, and M. Zelson, "Stress recovery during exposure to natural and urban environments," Journal of Environmental Psychology, vol. 11, no. 3, pp. 201-230, 1991.

[20] A. Huet and G. Saez, Le Règne des Loisirs. Loisirs Culturels et Sportifs, Dynamiques Socio Spatiales, Éditions De L'aubeDatar, 2002.

[21] T. Takano, K. Nakamura, and M. Watanabe, "Urban residential environments and senior citizens' longevity in megacity areas: the importance of walkable green spaces," 
Journal of Epidemiology \& Community Health, vol. 56, no. 12, pp. 913-918, 2002.

[22] J. Maas and R. Verheij, "Green space, urbanity, and health: how strong is the relation?," Journal of Epidemiology \& Community Health, vol. 60, no. 7, pp. 587-592, 2006.

[23] M. Beaudoin and M.-E. Levasseur, Verdir les Villes Pour la Santé de la Population, Institut National de Santé Publique, Phnom Penh, Cambodia, 2017.

[24] WHO, Urbanisme et Santé. S2D/Association Internationale Pour la Promotion de la Santé et du Développement Durable, WHO, Geneva, Switzerland, 2004.

[25] WHO, La Sédentarité: un Problème de Santé Publique Mondiale, WHO, Geneva, Switzerland, 2008, http://www. who.int/dietphysicalactivity/factsheet_inactivity/fr/.

[26] G. O. Robinette, Plants, People, and Environmental Quality; a Study of Plants and their Environmental Functions, U.S. Depatment of the Interior, National Park Service, Washington, DC, USA, 1972.

[27] M. De Sablet, Des Espaces Urbains Agréables à Vivre: Places rues Squares et Jardins, Le Moniteur, 1991.

[28] D. Nzala and P. Miankodila, "Arbres et espaces verts à Brazzaville (Congo)," Bois et Forêts des Tropiques, vol. 272, no. 2, pp. 88-92, 2002.

[29] V. Kimpouni, S. D. Mbouba, and M. Motom, "Étude de la flore allochtone arborescente et foresterie urbaine à Brazzaville (Congo)," Journal de Botanique de la Société Botanique de France, vol. 79, pp. 73-92, 2017.

[30] P. Vennetier, Atlas de la République Populaire du Congo, Jeune Afrique, Paris, France, 1977.

[31] CNSEE, Recensement Général de la Population et de l'Habitat de 2007; en Quelques Chiffres, MEPATI, UNFPA, Brazzaville, Congo, 2010.

[32] Cerape-Sofreco, Monographie départementale de Brazzaville, étude du Secteur Agricole, République du Congo, 2011.

[33] G. Samba and D. Nganga, "Rainfall variability in CongoBrazzaville: 1932-2007," International Journal of Climatology, vol. 32, no. 6, pp. 854-873, 2011.

[34] G. Samba, D. Nganga, and M. Mpounza, "Rainfall and temperature variations over Congo-Brazzaville between 1950 and 1998," Theoretical and Applied Climatology, vol. 91, no. 1-4, pp. 85-97, 2008.

[35] L. Makany, Végétation des Plateaux Téké (Congo), Collection: Travaux de l'université de Brazzaville, Brazzaville, Congo, 1976.

[36] Certu, "Caractérisation des espaces verts publics en fonction de leur place dans le milieu urbain," CERTU/ADF, Lyon, France, Guide Pour un Urbanisme, 2009.

[37] A. Jarnier, Les Modes D'appropriation d'un Parc Urbain Usages Différenciés d'un Espace Vert en Fonction des Populations, PFE, New York, NY, USA, 2011.

[38] S. Richard, La Politique et la Place des Espaces Verts en Milieu Urbain: cas d'Étude des Six Préfectures Départementales de la Région Centre, Université François Rebelais, Tours, Master de Géographie, 2013.

[39] Certu, Urbanisme et Santé. Guide pour Un Urbanisme, CERTU/ADF, Lyon, France, 2012.

[40] B. Deák, B. Hüse, and B. Tóthmérész, "Grassland vegetation in urban habitats-testing ecological theories," Tuexenia, vol. 36, pp. 379-393, 2016.

[41] V. Kimpouni, P. Mbou, E. Apani, and M. Motom, "Floristic diversity and structural parameters of the Brazzaville Patte d'Oie forest, Congo," Open Journal of Ecology, vol. 3, no. 8, pp. 518-531, 2013.
[42] V. Kimpouni, P. Mbou, G. Gakosso, and M. Motom, "Biodiversité floristique du sous-bois et régénération naturelle de la forêt de la Patte d'Oie de Brazzaville, Congo," International Journal of Biological and Chemical Sciences, vol. 7, no. 3, pp. 1255-1270, 2013.

[43] V. Kimpouni, P. Mbou, E. Apani, and M. Motom, "Étude floristique des îlots forestiers naturels de la Patte d'Oie de Brazzaville, Congo," Acta Botanica Gallica, vol. 161, no. 1, pp. 63-79, 2014.

[44] V. Kimpouni, J. D. D. Nzila, C.-M. Massamba-Makanda, S. Yallo Mouhamed, and J.-P. Kampe, "Spatial analysis of the woody flora of the djoumouna peri-urban forest, Brazzaville (Congo)," Ecology and Evolutionary Biology, vol. 4, no. 1, pp. 1-10, 2019.

[45] V. Kimpouni, J. D. D. Nzila, C. M. Massamba-Makanda, S. Yallo Mouhamed, and J.-P. Kampe, "Phytodiversite et parametres de structure de la foret peri-urbaine de la Djoumouna, Brazzaville (Congo)," International Journal of Innovation and Scientific Research, vol. 37, no. 1, pp. 90-110, 2018.

[46] V. Le Houerou and J. Le Houerou, L'arbre de Voyageur Plante des Jardins de l'Afrique Tropicale, Les Nouvelles Éditions Africaines, Paris, France, 1987.

[47] S. V. Szokolay, Environmental Science Handbook for Architects and Builders, Construction Press, London, UK, 1980.

[48] A. Arnberger and R. Eder, "Exploring the heterogeneity of rural landscape preferences: an image-based latent class Approach," Landscape Research, vol. 36, no. 1, pp. 19-40, 2011.

[49] E. Dugas, Du sport aux activités physiques de loisirs: des formes culturelles et sociales bigarrés, sociologie, théorie et recherches, 2007.

[50] A. T. Kaczynski and K. A. Henderson, "Environmental correlates of physical activity: a review of evidence about parks and recreation," Leisure Sciences, vol. 29, no. 4, pp. 315-354, 2007.

[51] J. Maas, S. M. E. Van Dillen, R. A. Verheij, and P. P. Groenewegen, "Social contacts as a possible mechanism behind the relation between green space and health," Health \& Place, vol. 15, no. 2, pp. 586-595, 2009.

[52] M. D. Velarde, G. Fry, and M. Tveit, "Health effects of viewing landscapes-landscape types in environmental psychology," Urban Forestry \& Urban Greening, vol. 6, no. 4, pp. 199-212, 2007.

[53] R. Ulrich, "View through a window may influence recovery from surgery," Science, vol. 224, no. 4647, pp. 420-421, 1984.

[54] G. Lessard and E. Boulfroy, Les rôles de l'arbre en ville. Centre collégial de transfert de technologie en foresterie de SainteFoy (CERFO), Québec, 2008.

[55] C. Bouka Biona and M. Mpounza, Impacts des Effets Actuels et Attendus du Changement Climatique en République du Congo, SIFEE, Niamey, Niger, 2008.

[56] P. Desanker and C. Justice, "Africa and global climate change: critical issues and suggestions for further research and integrated assessment modeling," Climate Research, vol. 17, pp. 93-103, 2001.

[57] D. D. Milošević, S. M. Savić, V. Marković, D. Arsenović, and I. Šećerov, "Outdoor human thermal comfort in local climate zones of Novi Sad (Serbia) during heat wave period," Hungarian Geographical Bulletin, vol. 6, no. 2, pp. 129-137, 2016.

[58] S. Jacquet, "Étude de la performance énergétique d'une toiture végétale extensive installée au centre-ville de Montréal," École de Technologie Supérieure, Montréal, Canada, Mémoire de Maîtrise Électronique, 2010. 
[59] M. Sajdak and B. Velazquez-Marti, "Estimation of pruned biomass form dendrometric parameters on urban forests: case study of Sophora japonica," Renewable Energy, vol. 47, pp. 188-193, 2012.

[60] R. B. Tabue Mbobda, "Diversité floristique et stock de carbone dans la partie Est de la Réserve de Faune du DJA," Université de Yaoundé I, Yaoundé, Cameroon, Mémoire de Master en Biologie des Organismes Végétaux, 2013.

[61] R. Prat, Biologie Végétale; Croissance et Développement, Editions Dunod, Paris, France, 2012.

[62] V. Kimpouni, M. Y. Lenga Sacadura, R. C. Nkounkou Loufoukou, and J. C. Mamboueni, "Survey of the anthropic actions and the urban woody flora exploitation in Brazzaville (Congo)," International Journal of Current Research and Academic Review, vol. 5, no. 7, pp. 38-51, 2017.

[63] P. Cornut, Petit historique de la convention Climat et des négociations climat, Les cahiers de Global Change no. 8, 1997.

[64] A. Angelsen, M. Brockhaus, W. D. Sunderlin, and L. V. Verchot, Analyse de la REDD+: les Enjeux et les choix, CIFOR, Bogor, Indonésie, 2013.

[65] GIEC, Guidelines for National Greenhouse Gas Inventories, Agriculture, Forestry and other Land Uses, vol. 4, IPCC, Institute for Global environmental strategies, Hayama, Japan, 2006.

[66] GIEC, Résumé à L'intention des décideurs, changements climatiques 2013: les éléments scientifiques," Contribution du Groupe de travail I au Cinquième Rapport D'évaluation du Groupe D'experts Intergouvernemental sur l'évolution $d u$ Climat, G.-K. Plattner et al., Ed., Cambridge University Press, Cambridge, UK, 2013.

[67] L. Nsiloulou, "Les arbres dans la ville de Brazzaville," Département de Géographie, FLSH, UMNG, Brazzaville, Congo, Mémoires de maîtrise, 2002. 